УДК 347.1

\author{
Ю.В.Кривенко \\ кандидат юридичних наук, \\ доцент кафедри цивільного права \\ Національного університету «Одеська юридична академія»
}

\title{
ОКРЕМІ ПИТАННЯ ЩОДО ПРАВА ВЛАСНОСТІ НА МАЙНО РЕЛІГІЙНИХ ОРГАНІЗАЦІЙ
}

У суспільній свідомості відбувається зміна одних ціннісних орієнтирів на інші, і у вітчизняній реальності все більше суспільне визнання отримують матеріально-економічні чинники. Одночасно з цим процес суспільно-соціальних перетворень відроджує традиційно-національні цінності, в тому числі і релігійні.

Релігійний вплив на суспільне життя стає останнім часом усе більш відчутним як у його позитивних, так і в негативних проявах. Зростає інтерес до релігії, з'являються тисячі нових парафій, громад, місій різних релігійних напрямів. Важливе місце в якісному оновленні належить змінам у духовному житті українського суспільства, синод Вселенського патріархату в Стамбулі надав Україні Томос [1] про автокефалію Православної церкви.

Релігійна організація як найстаріший ідеологічний і політичний інститут людства завжди посідала особливе місце в державній політиці. Релігійні організації самі по собі є носіями економічних інтересів, позаяк володіють неабиякою власністю, доходами. Вони мають у своєму розпорядженні численні спеціалізовані установи в сфері освіти, охорони здоров'я, соціальної допомоги. За рахунок власних коштів ведуть роботу в соціальній сфері, внаслідок чого звільняють частково від витрат місцеві бюджети, здійснюють будівництво.

Внаслідок цього нагальними є питання щодо правового статусу релігійних організацій, щодо права власності на майно та низка інших, які потребують вирішення.

Останнім часом у публікаціях розкриваються правові питання діяльності релігійних організацій, але вони не носять комплексного характеру, позаяк стосуються лише окремих сторін правового статусу релігійних організацій, визначають окремі питання щодо майна (включаючи спірні питання щодо нерухомості та земельних ділянок). І. Кучеренко, В. Піддубна, Л. Ярмол, Є. Ятченко, О. Шевченко висвітлювали в своїх працях питання, пов'язані з джерелами формування майна та об'єктами права власності релігійних організацій, судовим захистом майнових прав. Слід визнати, що натепер можливості релігійних організацій у приватно-правовій сфері значно розширилися, не можна не відзначити, що на цьому позитивному тлі у останніх виникає чимало проблем, пов'язаних з іноді не досить продуманим і не повністю систематизованим законодавчим регулюванням їхнього правового статусу та майновими питаннями. Істотна зміна державної політики стосовно релігійних організацій вплинула на внесення відповідних змін до чинного законодавства. Хоча такі зміни в цілому мають позитивне значення, законодавче регулювання в цій сфері не позбавлене серйозних недоліків, що й спричиняє необхідність поглибленого дослідження цієї проблеми.

Метою статті є вивчення питань, пов'язаних з правом власності релігійних організацій, виробленням пропозицій і нових підходів та його правового регулювання.

Завданнями відповідно до вказаної мети є:

- аналіз цивільно-правового регулювання діяльності релігійних організацій як суб'єктів цивільно-правових відносин;

- визначення проблематики питань щодо права власності на майно релігійних організацій.

Об'єктом дослідження є релігійні організації (а саме особливості їх економічного становища) як суб'єкти цивільно-правових відносин та учасники цивільних правовідносин.

Предметом дослідження є право власності релігійних організацій. При цьому, оскільки законодавство не виділяє релігійні організації особливими суб'єктами права, то слід приділити увагу як загальним проблемам права власності, так і визначити специфіку, якою наділені релігійні організації в цьому питанні.

Останнім часом відбулася докорінна зміна в поглядах держави на релігійні організації та релігію в цілому. Тривалий час проголошені конституціями радянського періоду принципи взаємин держави і релігійних об'єднань практично не змінювалися, а нині набувають зовсім іншого трактування і за допомогою прийнятого законодавства, нарешті, починають поступово втілюватися в життя. Зміни торкнулися, в тому числі і цивільно-правового статусу релігійних організацій. На відміну від попереднього періоду, держава визначає, що релігійні організації є повноцінними учасниками цивільного обороту як інші юридичні особи. 3 цього часу почав поступово змінюватися статус релігійних організацій як суб'єктів цивільного права, і процес цей триває досі. Насамперед, безумовно, він торкнувся питань набуття права власності на майно релігійними організаціями.

Відповідно до статті 41 Конституції України [2] та пункту 2 частини першої статті 3 , статті 
321 ЦК [3] ніхто не може бути позбавлений права власності чи обмежений у його здійсненні, крім випадків, встановлених Конституцією та законом. Ураховуючи, що згідно зі статтею 92 Конституції України [4] правовий режим власності визначається виключно законами України, то інші нормативно-правові акти, які обмежують права власника і не мають ознак закону, не підлягають застосуванню.

$\mathrm{y}$ власності юридичних осіб може бути будьяке майно, крім того, яке через закон не може їм належати. Обмеження встановлюються законом з метою захисту основ конституційного ладу, моралі, здоров'я, законних прав та безпеки держави.

На перший погляд, перелік об'єктів права власності релігійних організацій не відрізняється від переліку інших юридичних осіб. Однак специфіка діяльності релігійних організацій накладає свій відбиток як на зміст і способи здійснення, так і на круг об'єктів власності зазначених організацій.

Майно, що перебуває у власності релігійних організацій, в основному призначене для групового використання під час здійснення релігійної та діяльності з нею пов'язаної. Воно, як правило, має невиробниче призначення, хоча це необов'язково. 3 метою недопущення необгрунтованого обмеження релігійних організацій законодавець в ст. 18 Закону України «Про свободу совісті та релігійні організації» визначає, що релігійні організації можуть бути обмежені у здійсненні права власності лише у випадках і в порядку, передбачених законом [5].

В юридичній літературі зроблена спроба класифікувати об'єкти права власності релігійних організацій. У цьому, безумовно, є необхідність, позаяк для окремих видів майна законодавець встановлює специфічний правовий режим. Крім того, внутрішніми нормами релігійних організацій також можуть бути встановлені особливі правила використання або обігу майна певного виду.

$\mathrm{У}$ третьому розділі (Майновий стан релігійних організацій) Закону визначені такі питання:

- користування майном, яке є власністю держави, громадських організацій або громадян;

- власності релігійних організацій;

- особливості здійснення виробничої та підприємницької діяльності;

- розпорядження майном релігійних організацій, що припинили свою діяльність [6].

Для здійснення різноманітної і широкомасштабної діяльності релігійним організаціям необхідна значна майнова і фінансова база.

Натепер релігійні організації як суб'єкти цивільного права наділені майновими правами - речовими і зобов'язальними. Стосовно їх здійснення до релігійних організацій застосовуються ті ж вимоги, що і до інших суб'єктів цивільного права, а також додаткові вимоги, які пов'язані зі специфікою їхньої діяльності. У зв’язку з цим є осо- бливості у реалізації ними права власності; права користування майном, що є власністю держави, громадян та їх об'єднань.

У власності релігійних організацій можуть бути будівлі, предмети культу, об'єкти виробничого, соціального і добродійного призначення, транспорт, кошти та інше майно, необхідне для забезпечення їхньої діяльності.

Релігійні організації мають право власності на майно, придбане або створене ними за рахунок власних коштів, пожертвуване громадянами, організаціями або передане державою, а також придбане на інших підставах, передбачених законом.

У власності релігійних організацій може бути також майно, що знаходиться за межами України.

Релігійні організації мають право звертатися за добровільними фінансовими та іншими пожертвуваннями і одержувати їх.

Під майном релігійного призначення мається на увазі майно, яке має цільове призначення та пов'язане з віросповіданням. Нерухомим майном релігійного призначення $є$ : культові будівлі із земельними ділянками, що їм належать, а також земельними ділянками, на яких безпосередньо розташовані культові будівлі, монастирські та інші культові комплекси, побудовані для здійснення та забезпечення богослужінь, молитовних і релігійних зібрань, інших релігійних обрядів і церемоній, а також будівлі професійної релігійної освіти. Рухомим майном релігійного призначення є предмети інтер'єру культових будівель або предмети, призначені для богослужіння та інших релігійних цілей. Культовий характер речей зумовлює їх особливий правовий режим - на рухоме і нерухоме майно богослужбового призначення не може бути звернено стягнення за претензіями кредиторів.

Культова будівля та інше майно, які становлять історичну, художню або іншу культурну цінність, передаються релігійним організаціям і використовуються ними з додержанням установлених правил охорони і використання пам'яток історії та культури.

Питання про джерела формування майна, що надходить у власність релігійних організацій Православної церкви України, - одне з найважливіших для характеристики їх суб'єктивного права власності.

Для існування та виконання статутних цілей та завдань релігійним організаціям необхідна матеріально-технічна база: будівлі, приміщення, гроші та інше майно. Джерела формування майна, як правило, створюються за рахунок власних коштів, це $€$ досить поширеним серед релігійних організацій. На практиці нерідко православні парафії зусиллями прихожан або своїх працівників займаються будівництвом тих чи інших підсобних приміщень, написанням і реставрацією ікон, створенням предметів, використовуваних під час богослужінь, 
і т.п. Але особливо поширена практика самостійного створення того чи іншого майна в православних монастирях. Це пов'язано насамперед зі специфікою внутрішнього устрою і цілей, переслідуваних монастирями. Оскільки цілями створення останніх $є$ не тільки віросповідання, а й віддалення ченців від світу, монастирі завжди прагнули до самодостатності і незалежності в економічному плані. Незважаючи на те, що в умовах сьогодення така самодостатність навряд чи можлива, монастирям, які розташовані в сільській місцевості, дуже властиві заняття городництвом, садівництвом, тваринництвом, рибальством і т.п., а ті, які розташовані в містах, займаються випічкою хлібобулочних виробів, швейним виробництвом та іншими видами діяльності для задоволення власних потреб.

Право власності на майно, «придбане за рахунок власних коштів», виникає у релігійних організацій на підставі укладення таких цивільно-правових договорів, як купівля-продаж, підряд, міна, поставка тощо, а також у результаті здійснення підприємницької діяльності.

Все майно, яке в своїй діяльності використовують релігійні організації, залежно від того, хто є власником, можна поділити на дві частини: майно, яким володіють на праві власності релігійні організації, та майно, яке належить на праві власності державі, іншим юридичним та фізичним особам.

Право користування релігійних організацій майном релігійного призначення, що перебуває у державній або муніципальній власності, є обмеженим речовим правом. Це підтверджується сукупністю таких ознак.

По-перше, вказане право носить постійний (по суті, безстроковий) характер - річ передається на той час, поки існує відповідна релігійна організація.

По-друге, його об’єктом є річ, що має релігійне призначення.

По-третє, перехід права власності на річ не передбачений як підстава припинення права користування релігійною організацією цією річчю (право слідування).

Основними джерелами фінансування церков $є$ церковні податки, які стягуються на суспільно корисні цілі, до числа яких належить: діяльність соціальних релігійних установ; добровільні внески за фіксованою ставкою; добровільні пожертвування фізичних і юридичних осіб на цільові і загальні витрати; щорічні та поточні пожертвування під час відвідування богослужінь. Крім перерахованих податків і внесків, церква отримує плату від віруючих за здійснення обрядів, доходи від церковного майна та господарської діяльності, дотації з державного бюджету на церковні, виховні та медичні установи, будинки для людей похилого віку, на підтримку і реставрацію пам'яток історії та культури, дотації від зарубіжних церков.
Відштовхуючись від зразкового переліку ст. 18 Закону [7], можна виділити:

1) майно, призначене для здійснення власне релігійної діяльності (предмети релігійного призначення), яке, своєю чергою, можна поділити на: речі священні та речі церковні. До першої групи належать усі предмети, спеціально призначені для здійснення богослужіння; до другої - будьяке інше церковне майно.

Священні предмети, своєю чергою, поділяють на священні у власному розумінні цього слова і освячені. Річ стає священною через її освячення або через сам характер її вживання у богослужінні.

Під майном релігійного призначення мається на увазі майно, яке має цільове призначення, пов'язане з віросповіданням. Відповідно до церковних канонів священні предмети не можуть використовуватися як звичайні. До звичайного церковного майна належать усі нерухомі та рухомі речі, гроші, призначені для утримання релігійної організації, духовенства i для задоволення загальноцерковних потреб. Нерухомим майном релігійного призначення є: культові будівлі із земельними ділянками, які до них належать, монастирські та інші культові комплекси, побудовані для здійснення та забезпечення богослужінь, молитовних і релігійних зібрань, інших релігійних обрядів і церемоній, а також будівлі професійної релігійної освіти. Рухомим майном релігійного призначення є предмети інтер'єру культових будівель або предмети, призначені для богослужбових та інших релігійних цілей. Майно релігійного призначення має використовуватися за цільовим призначенням.

2) майно, призначене для здійснення інших форм діяльності релігійної організації (благодійної, соціальної, культурно-просвітницької);

При релігійних організаціях можуть утворюватися товариства, братства, асоціації, інші об'єднання громадян для здійснення доброчинності, вивчення та розповсюдження релігійної літератури та іншої культурно-освітньої діяльності [8, с. 45].

3) майно, призначене для здійснення виробничої та підприємницької діяльності.

Натепер одним 3 найбільш значущих джерел формування майна релігійних організацій $є$ підприємницька діяльність. I це не випадково. Адже закон надав релігійним організаціям набагато ширші можливості в цій сфері, ніж були раніше.

Таким чином, слід зазначити, що релігійні організації для існування та виконання статутних завдань набувають майно, призначене для здійснення власне релігійної діяльності, для здійснення інших форм діяльності релігійної організації (благодійної, соціальної, культурно-просвітницької) та майно, призначене для здійснення виробничої та підприємницької діяльності. Враховуючи те, що предмети інтер'єру культових будівель або предмети, призначені для богослужбових та 
інших релігійних цілей, мають історичне та культурне значення, є доцільним створення єдиного реєстру, що сприятиме збереженню та забезпечить належне використання.

\section{Jimepamypa}

1. Синод у Стамбулі вирішив надати Україні Томос про автокефалію. URL: https://ukr.segodnya.ua/ ukraine/oficialno-sinod-v-stambule-reshil-predostavitukraine-tomos-ob-avtokefalii-1178800.html.

2. Конституція України. Відомості Верховної Ради України (ВВР), 1996, № 30, ст. 14.

3. Цивільний кодекс України. Відомості Верховної Ради України (ВВР), 2003, №№ 40-44, ст. 356.

4. Конституція України. Відомості Верховної Ради України $(B B P), 1996$, № 30, ст. 14.

5. Про свободу совісті та релігійні організації : Закон України. Відомості Верховної Ради УРСР (BВP), 1991, № 25, ст. 283.

6. Про свободу совісті та релігійні організації : Закон України. Відомості Верховної Ради УРСР (BВP), 1991, № 25, ст. 283.

7. Про свободу совісті та релігійні організації : Закон України. Відомості Верховної Ради УРСР (BВP), 1991, № 25, ст. 283.

8. Новіков В.В. До питання про благодійну діяльність релігійних організацій. Наукові записки Львівського університету бізнесу та права. 2013. Вип. 10. C. $45-49$.

\section{Анотація}

Кривенко Ю. В. Окремі питання щодо права власності на майно релігійних організацій. - Стаття.

Стаття присвячена питанням права власності на майно релігійних організацій. Релігійний вплив на суспільне життя стає останнім часом усе більш відчутним як у його позитивних, так і в негативних проявах. Зростає інтерес до релігії, з'являються нові парафії, громади, місії різних релігійних напрямів. Тривалий час питання права власності вирішувалося аж ніяк не на користь релігійних організацій. Натепер у власності релігійних організацій можуть бути будівлі, земельні ділянки, об’єкти виробничого, соціального, благодійного, культурно-просвітницького та іншого призначення, в тому числі, які визначенні як історично-культурна пам'ятка.

Майно, яке в своїй діяльності використовують релігійні організації, залежно від того, хто є власником, можна поділити на дві частини: майно, яким володіють на праві власності релігійні організації, та майно, яке належить на праві власності державі, іншим юридичним та фізичним особам.

Необхідно звернути увагу на майно релігійного призначення, яке належить релігійним організаціям. Нерухомим майном релігійного призначення є: культові будівлі із земельними ділянками, які до них належать, монастирські та інші культові комплекси, побудовані для здійснення та забезпечення богослужінь, молитов- них і релігійних зібрань, інших релігійних обрядів і церемоній, а також будівлі професійної релігійної освіти. Рухомим майном релігійного призначення є предмети інтер'єру культових будівель або предмети, призначені для богослужбових та інших релігійних цілей. Майно релігійного призначення використовується у відповідності до призначення та зумовлює особливий правовий режим - на рухоме і нерухоме майно богослужбового призначення не може бути звернено стягнення за претензіями кредиторів.

Слід зазначити, що законодавець більш детально регулює питання щодо нерухомого майна релігійного призначення, визначаючи історичну та культурну цінність, а от щодо рухомого майна релігійного призначення $є$ низка питань, які потребують подальшого урегулювання.

Ключові слова: релігійні організації, право власності, майно, майно релігійного призначення.

\section{Summary}

Kryvenko Yu. V. Separate issues regarding property right of religious organizations property. - Article.

The article is devoted to issues of property ownership of the religious organizations. Religious influence on public life is becoming more and more tangible in recent times, both in its positive and in negative manifestations. There is a growing interest in religion, new parishes, communities, different religious mission. For a long time, issue of property rights wasn't resolved in favor of religious organizations. For today, religious organizations may own buildings, land, objects of production, social, charitable, cultural and educational, and other purposes, including which are defined as a historical and cultural monument. The property which religious organizations use in their activity, depending on who the owner is, can be divided into two parts: property owned by religious organizations, and property owned by the state, other legal entities and individuals. It is necessary to pay attention to religious property belonging to religious organizations. Real estate of religious significance are: religious buildings with the land belonging to them, monastic and other religious complexes, constructed for the implementation and maintenance of worship, prayer and religious gatherings, other religious rites and ceremonies, and buildings professional religious education. Movable property for religious purposes is the interior of religious buildings or objects intended for liturgical and other religious purposes. The property used for religious purposes in accordance with the purpose and makes them special legal regime movable and immovable property liturgical purpose can't be seized by creditors' claims.

It should be noted that legislator more closely regulates issues of immovable property for religious purposes, defining historical and cultural value, but concerning movable property of religious significance there are a number of issues that require further regulation.

Key words: religious organization, ownership, property, property for religious purposes. 